\title{
Penerapan Algoritma Support Vector Machine (SVM) untuk Klasifikasi Berita Hoax Covid-19
}

\author{
Isnin Apriyatin Ropikoh ${ }^{1 *}$, Rijal Abdulhakim ${ }^{2,}$ Ultach Enri $^{3 *}$, Nina Sulistiyowati ${ }^{4 *}$ \\ * Teknik Informatika, Universitas Singaperbangsa Karawang \\ isnin.apriyatin17029@student.unsika.ac.id ${ }^{1}$, rijal.abulhakim16182@ @student.unsika.ac.id, ${ }^{2}$, ultach@staff.unsika.ac.id ${ }^{3}$, \\ nina.sulistio@unsika.ac.id ${ }^{4}$
}

\begin{tabular}{l} 
Article Info \\
\hline Article history: \\
Received 01-07-2021 \\
Revised 16-07-2021 \\
Accepted 19-07-2021 \\
\hline
\end{tabular}

Keyword:

Covid-19,

Hoax,

$K D D$,

Klasifikasi,

SVM.

\begin{abstract}
Seiring dengan perkembangan teknologi informasi, media berita juga turut berkembang menyajikan informasi dalam media online. Namun, sangat disayangkan pada penyebarannya masih banyak ditemukan berita hoax atau tidak benar. Berita hoax yang paling mudah beredar adalah hoax tentang kesehatan. Di Indonesia sendiri semenjak diberitakan masuknya virus Covid-19, berita hoax tentang hal itu terus meningkat berdasarkan data yang dirilis oleh Kominfo periode Januari-Agustus 2020. Agar terhindar dari berita hoax ialah dengan lebih teliti membaca judul berita pada situs yang terpercaya seperti Kompas. Karena itu penelitian ini akan mengembangkan dan menganalisis model klasifikasi berita hoax Covid-19 dengan menerapkan algoritma Support Vector Machine (SVM) dengan metodologi Knowledge Discovery in Databases (KDD). Studi kasus penelitian ini dibagi dalam 2 kategori yaitu berita hoax yang didapat dari situs Trunbackhoax \& Hoax buster sedangkan berita bukan hoax diambil dari situs berita Kompas. Hasil penelitian menyatakan bahwa Algoritma Support Vector Machine (SVM) dengan kernel linear memiliki hasil prediksi yang bagus pada skenario 3 (80:20) karena model sanggup dalam mengklasifikasikan berita hoax dan bukan hoax Covid-19. Akurasi yang didapat pada skenario 3 juga memiliki nilai akurasi tertinggi sebesar 97,06\%. Sedangkan pada kernel RBF memiliki akurasi terendah pada skenario 4 (90:10) yaitu $90.46 \%$ dan model kurang bagus dalam mengklasifikasikan berita hoax maupun bukan hoax Covid-19.
\end{abstract}

This is an open access article under the CC-BY-SA license.

\section{Pendahuluan}

Berdasarkan Kamus Besar Bahasa Indonesia (KBBI) 2021, dijelaskan bahwa informasi tidak benar atau palsu yang didapat tanpa sumber yang jelas merupakan pengertian dari hoax [1]. Sedangkan dalam Oxford English Dictionary [2], hoax didefinisikan sebagai suatu tindakan atau perbuatan yang dibuat dengan tujuan untuk membuat orang lain mempercayai sesuatu yang tidak benar. Masyarakat memiliki penjelasan tersendiri mengenai hoax. Berdasarkan survey yang dilakukan oleh "Masyarakat Telematika Indonesia (MASTEL)" pada 2019 dan diikuti sebanyak 941 responden mendapatkan hasil bahwa $88 \%$ memilih penjelasan berita hoax sebagai berita tidak benar dan sengaja dibuat, $49 \%$ menjawab berita penghasut, $15 \%$ menyebutkan hoax merupakan berita perkiraan atau yang berkaitan dengan sains, $14 \%$ menyebutkan sebagai berita yang membuat pemerintah merasa terpojokan, $31 \%$ menganggap berita hoax untuk menjelekan orang lain dan $1 \%$ lainnya menjawab tidak tahu mengenai definisi hoax [3].

Berdasarkan data dari situs datareportal, pengguna internet dari januari tahun 2019 [4] sampai januari 2020 [5] mengalami peningkatan sekitar 25 juta pengguna. Menurut Jamalul izza, peningkatan terjadi disebabkan oleh pemerataan infrastruktur internet dengan adanya Palapa Ring [6]. Hal ini merupakan salah satu faktor yang mempengaruhi penyebaran informasi menjadi tidak terkendali, sehingga berbagai informasi dapat diakses oleh masyarakat melalui internet tanpa validasi, dimana informasi itu dapat berupa 
berita palsu atau hoax. Peningkatan jumlah pengguna internet dapat dilihat pada gambar 1 berikut.

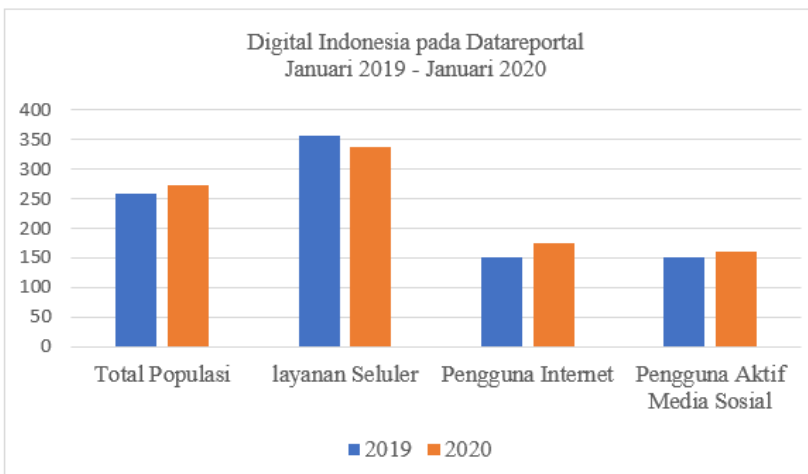

Gambar 1. Digital Indonesia dari Datareportal

Kata berita sendiri menurut Kamus Besar Bahasa Indonesia (KBBI), 2021 merupakan suatu informasi yang menunjukan tempat atau keterangan waktu dan biasanya terjadi di masyarakat [7]. Seperti telah disinggung sebelumnya, penyebaran berita dapat berupa informasi palsu atau kebohongan yang akan dulit dikendalikan apalagi dengan kondisi yang belum dapat dipastikan. Sekretaris Dewan Kehormatan Persatuan Wartawan Indonesia (PWI), Wina Armanda Sukardi menyampaikan bahwa berita hoax tentang kesehatan adalah yang paling banyak beredar menurut survey yang dilakukan sejak Februati 2016 sampai Februari 2017. Dengan kurang lebih seribu sampel, hoax kesehatan mendapat nilai tertinggi yaitu sebanyak $27 \%$, posisi kedua merupakan berita hoax politik sebanyak $22 \%$, berita hoax hiburang sebanyak $15 \%$ dan sisanya merupakan berita hoax mengenai bisnis dan lainnya [8]. Dapat diketahui bahwa berita hoax kesehatan adalah hoax yang populer jika dibandingkan dengan berita lainnya. Berdasarkan data yang dirilis oleh Kominfo melalui website resminya telah mencatat dari bulan Januari - Agustus 2020 bahwa sebanyak 1028 hoaks tersebar terkait berita Covid-19. Dalam hal ini, berita hoaks covid merupakan salah satu berita hoaks kesehatan yang paling banyak penyebarannya seperti ditamilkan pada table berikut.

TABEL I

DATA HOAX TERKAIT COVID-19

\begin{tabular}{|c|c|}
\hline Bulan & Berita Hoax \\
\hline Januari & 40 \\
\hline Februari & 100 \\
\hline Maret & 265 \\
\hline April & 219 \\
\hline Mei & 172 \\
\hline Juni & 102 \\
\hline Juli & 108 \\
\hline Agustus (8 Agustus) & 22 \\
\hline Total & $\mathbf{1 . 0 2 8}$ \\
\hline (Sumber: https://kominfo.go.id/content/detail/28536/kominfo-mencatat-
\end{tabular}

sebanyak-1028-hoaks-tersebar-terkait-covid-19/0/sorotan_media)

Di masa pandemi covid-19 ini, banyak masyarakat mencari informasi mengenai virus seperti awal mula terbentuknya virus, gejala, cara pengobatan dan berbagai informasi lainnya. Namun sejak diberitakan masuknya virus Covid-19 ke Indonesia pada 2 Maret 2020 oleh Presiden RI Joko Widodo yang menjangkit 2 warga negara Indonesia [9], membuat penyebaran informasi hoax mengenai virus tersebut semakin marak dan tidak terkendali seperti dapat dilihat pada gambar 1 .

Pada tahun 2020 dilakukan survey oleh Juditha [10] dengan 625 responden dengan kategori pengguna internet yang menetap di Indonesia mengdapatkan hasil bahwa masyarakat Indonesia mendapatkan informasi mengenai Covid-19 dari media online (situs berita) sebanyak 89,9\% dimana merupakan yang terbanyak, lalu dari media sosial sebanyak $83,70 \%$, dari televisi $78,20 \%$, melalui pesan instan sebanyak $69,60 \%$ dan $65 \%$ dari website resmi pemerintah, sedangkan $60 \%$ lainnya dari media lain. Sehingga berdasarkan survey tersebut, media online merupakan sumber informasi yang paling ditunngu.

Salah satu cara untuk tidak terjerumus pada berita hoax adalah dengan membaca berita atau infomasi dari media terpercaya. Kompas salah satu situs berita online yang mendapat dua kali penghargaan oleh Suoerbrands untuk kategori berita online terpercaya [11]. Selain itu kompas secara resmi tersertifikasi dalam jaringan internasional penguuji fakta (IFCN - International Fact-Checking) [12].

Berita mengenai hoax dapat diakses melalui situs Turnbackhoax \& Hoax-buster. Turnbackhoax merupakan situs pengaduan berbagai jenis hoax. Situs ini dibuat oleh KOMINFO \& MASTEL [13]. Sedangkan hoax buster merupakan bagian dari website www.covid19.co.id yang secara resmi telah diluncurkan oleh gugus tugas penanganan covid-19 dibuat dengan tujuan sebagai acuan apakah informasi tersebut merupakan hoax berita covid-19 di Indonesia [14].

Menurut Monarizqa et al [15], text mining merupakan proses penambangan pengetahuan dan informasi data berupa teks atau dokumen. Hal ini bertujuan untuk mendapatkan informasi dari sekumpulan format teks yang tidak terstruktur [16]. Salah satu bagian dari text mining adalah klasifikasi, dimana klasifikasi ialah proses prediksi pada kelas objek yang belum diketahui kelas dan karakteristik tipe data klasifikasinya [17]. Proses klasifikasi dapat menggunakan algoritma Decission Tree, $K$-Nearest Neighbor (KNN), Naive Bayes, Neural Network (NN), Random Forest (RF) dan Support Vektor Machine (SVM).

Algoritma Support Vector Machine (SVM) merupakan metode yang paling populer digunakan untuk klasifikasi berita hoax menurut survey yang dilakukan pada 2016-2018 [16]. Penelitian tersebut menggunakan fungsi kernel SVM [18] yaitu kernel Linear dengan metode cross validation fold 10 mendapatkan nilai akurasi sebesar 95,84\%. Perhitungan akurasi SVM lebih unggul dengan nilai akurasi pada proses $k$-fold validation sebesar $88,76 \%$ dibandingkan dengan Algoritma KNN dengan akurasi $88,1 \%$. Kemudian perbandingan SVM dengan Multinominal Naive Bayes 
$(M N B)[19]$ mendapatan hasil SVM lebih unggul dengan akurasi sebbesar $82 \%$, presisi $84 \%$ dan recall $82 \%$. Sedangkan MNB memperoleh akurasi sebesar 62\%, presisi $68 \%$ dan recall $62 \%$.

Penelitian yang membandingkan empat fungsi linear untuk mengklasifikasikan helpdesk dengan metode SVM menghasilkan akurasi paling tinggi pada kernel RBF atau gaussian dengan nilai $81 \%$, kernel linear dan polynomial mendapatkan nilai setara dengan $78 \%$ serta kernal sigmoid mendapatkan nilai terendah dengan 51\% [20]. Kemudian pada penelitian lain yang serupa [21] mendapatkan hasil akurasi tertinggi pada RBF 81,44\%, kernel linar sebesar $81,26 \%$ dan polynomial $67,12 \%$. Namun pada nilai presisi, recall dan fl-score kernel linear justru mendapatkan nilai tertingi dengan $90 \%$, $89 \%$ dan $89 \%$ secara berurutan.

Berdasarkan pada penelitian sebelumnya, maka penelitian ini akan menggunakan metode klasifikasi dengan menetapkan algoritma Support Vektor Machine (SVM) dengan dua fungsi kernel linear dan kernel RBF. Serta dataset yang digunakan diambil dari situs berita online Kompascom untuk berita bukan hoax dan situs Turnbackhoax \& hoaxbuster untuk berita hoax pada periode Maret 2020 sampai Desember 2020.

\section{Metode Penelitian}

\section{A. Metodologi Penelitian}

Penelitian menggunakan Algoritma Support Vector Machine (SVM) untuk klasifikasi berita hoax Covid-19. Dengan metodologi Knowledge Discovery in Database $(K D D)$. Metode KDD ini dapat berguna menemukan suatu teknik dari database yang ada. Terdapat 5 proses text mining dalam tahapan KDD yaitu, data selection, preprosessing, transformastion, data mining dan evaluation.

\section{B. Rancangan Penelitian}

Penelitian ini akan menggunakan bahasa pemrograman Phyton 3, dengan rancangan penelitian seperti berikut.

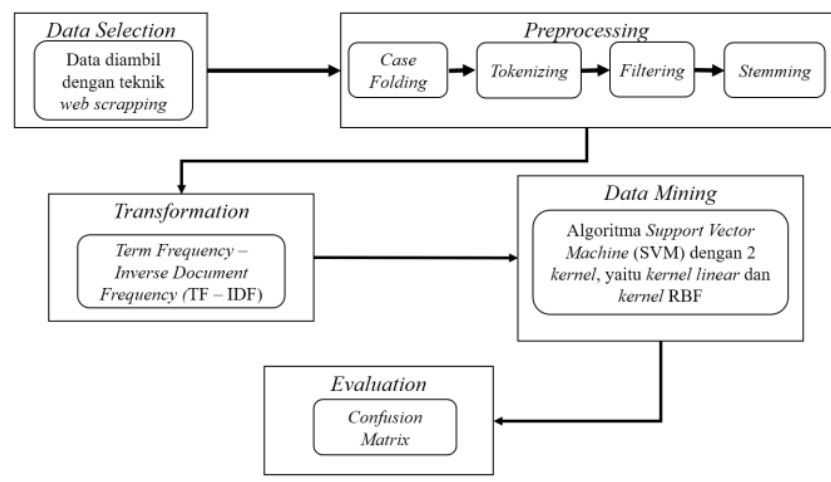

Gambar 2. Rancangan Penelitian.

\section{HASIL DAN PEMbahasan}

\section{A. Hasil Penelitian}

Pennelitian ini menggunakan proses text mining, hasil penelitian yang sudah dilakukan yaitu bagaimana menerapkan algoritma Support Vektor Machine (SVM) dengan dua fungsi kernel yaitu kernel linear dan kernel RBF untuk menghasilkan berita hoax dan bukan hoax dengan menggunakan data berita Covid-19 yang diambil dari situs online.

1) Data Selection: Data diambil menggunakan teknik web scramping dengan Phyton 3. Data awal memiliki 3 atribut yaitu Judul, Tanggal dan Sumber. Kemudian data dikonversikan berdasarkan tanggal agar data konsisten. Data yang digunakan adalah data berita Covid-19 pada tanggal 1 Maret 2020 sampai 31 Desember 2020 yang diperoleh dari 3 situs berita online dengan kategori berita hoax dan berita bukan hoax. Data yang akan diproses berjumlah 8.172 dataset yang berisikan 837 berita hoax dan 7.335 berita bukan hoax. Contoh data judul berita dapat dilihat pada tabel berikut.

TABEL II

CONTOH DATASET

\begin{tabular}{|c|l|c|c|}
\hline No. & \multicolumn{1}{|c|}{ Judul } & Sumber & Label \\
\hline 1 & $\begin{array}{l}\text { [SALAH] Orang yang Bergolongan } \\
\text { Darah O Lebih Rentan Terinfeksi } \\
\text { Virus Corona }\end{array}$ & Turnbackhoax & 0 \\
\hline 2 & $\begin{array}{l}\text { [SALAH] Area Kantor Nokia di } \\
\text { Menara Mulia Dibersihkan Setelah } \\
\text { Ada Karyawan Meninggal }\end{array}$ & Turnbackhoax & 0 \\
\hline 3 & $\begin{array}{l}\text { [SALAH] "Jokowi hari ini tolak } \\
\text { disuntik vaksin Covid-19 duluan" }\end{array}$ & Hoaxbuster & 0 \\
\hline 4 & $\begin{array}{l}\text { [SALAH] Video Perawat Pingsan } \\
\text { Setelah Mendapat Vaksin Covid- } \\
19, \text { Potensi Genosida Massal }\end{array}$ & Hoaxbuster & 0 \\
\hline 5 & $\begin{array}{l}\text { Update Virus Corona 2 Maret: } \\
89.212 \text { Orang di 68 Negara } \\
\text { Terinfeksi }\end{array}$ & Kompas & 1 \\
\hline 6 & $\begin{array}{l}\text { Bertambah 34 Negara dalam } \\
\text { Sepekan, Ini Daftar 64 Negara } \\
\text { Terinfeksi Virus Corona }\end{array}$ & Kompas & 1 \\
\hline 7 & $\begin{array}{l}\text { Update Terbaru Virus Corona: } \\
\text { Positif di 64 Negara, 3.006 Orang } \\
\text { Meninggal, 88.227 Terinfeksi }\end{array}$ & $\begin{array}{l}\text { Hadapi Corona, Wali Kota Jakbar } \\
\text { Imbau Stop Panic Buying }\end{array}$ & Kompas \\
\hline
\end{tabular}

Pelabelan dilakukan secara manual dengan ketentuan label (0) untuk berita hoax dengan alasan mengandung kata atau isi berita yang tidak sesuai dengan fakta sebenarnya berasal dari situs turnbackhoax.id, sedangkan berita bukan hoax diberi label (1) yang berasal dari situs berita online Kompascom dan Detikcom dimana merupakan berita dengan isi berita mengandung fakta sebenarnya yang terjadi pada masyarakat.

2) Pre-processing: pada bagian ini terdapat beberapa tahap yang harus dilakukan yaitu tahap case folding, tokenizing, filtering dan stemming.

a) Pada tahap case folding dilakukan penyeragaman kata, dimana huruf atau kata yang semula kapital (uppercase) 
diubah menjadi hurud kecil (lowercase). Berikut contoh tahap case folding:

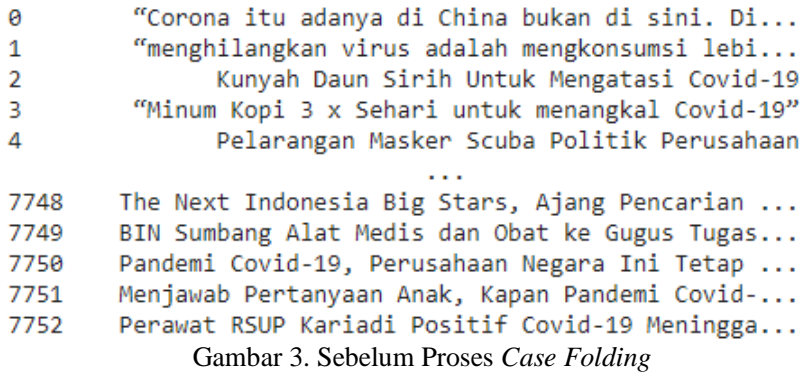

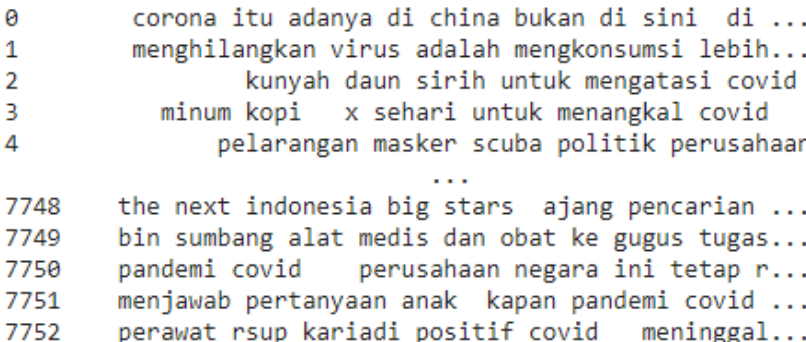

b) Tahap Tokenizing merupakan proses selanjutnya setelah dilakukan Case Folding, dimana proses ini merupakan kegiatan dengan tujuan untuk memecah sebuah kalimat ke dalam kepingan-kepingan kata agar dapat diketahui kata mana yang merupakan kata benda, kata sifat, kata kerja, kata sambung dan tanda baca pada sebuuah kalimat, kemudian kata yang tidak dibutuhkan dapat dihilangkan.

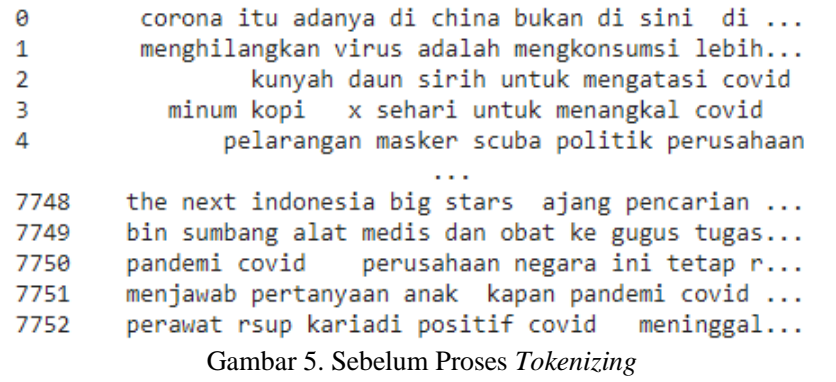

0 [corona, itu, adanya, di, china, bukan, di, si... 1 [menghilangkan, virus, adalah, mengkonsumsi, $1 .$. 2 [kunyah, daun, sirih, untuk, mengatasi, covid] 3 [minum, kopi, $x$, sehari, untuk, menangkal, covid] 4 [pelarangan, masker, scuba, politik, perusahaan]

7748 [the, next, indonesia, big, stars, ajang, penc... 7749 [bin, sumbang, alat, medis, dan, obat, ke, gug... 7750 [pandemi, covid, perusahaan, negara, ini, teta... 7751 [menjawab, pertanyaan, anak, kapan, pandemi, C... 7752 [perawat, rsup, kariadi, positif, covid, menin... Gambar 6. Setelah Proses Tokenizing

c) Filtering merupakan tahap pengambilan kata penting dari hasil tokenizing. Penghilangan kata sambung atau kata tidak penting dilakukan menggunakan teknik removes stopword. Stopword adalah kata tidak deskriptif yang dapat dibuang ke dalam bag of word.

0
1
2
3
4
7748
7749
7750
7751
7752

0
1
2
3
4
7748
7749
7750
7751
7752

[corona, itu, adanya, di, china, bukan, di, si...
[menghilangkan, virus, adalah, mengkonsumsi, $1 .$. [menghilangkan, virus, adalah, mengkonsumsi, 1 .. [minum, kopi, x, sehari, untuk, menangkal, covid] [pelarangan, masker, scuba, politik, perusahaan]

[the, next, indonesia, big, stars, ajang, penc... [bin, sumbang, alat, medis, dan, obat, ke, gug... [pandemi, covid, perusahaan, negara, ini, teta... [menjawab, pertanyaan, anak, kapan, pandemi, c... [perawat, rsup, kariadi, positif, covid, menin... Gambar 7. Sebelum Proses Filtering

[corona, adanya, china, bukan, sini, sini, cum... [menghilangkan, virus, mengkonsumsi, lebih, ba... [kunyah, daun, sirih, mengatasi, covid] [minum, kopi, x, sehari, menangkal, covid] [pelarangan, masker, politik, perusahaan]

[the, indonesia, big, stars, ajang, pencarian,... [bin, sumbang, alat, medis, obat, gugus, tugas... [pandemi, covid, perusahaan, negara, tetap, ra... [menjawab, pertanyaan, anak, kapan, pandemi, c... 「perawat, rsup, kariadi, positif, covid, menin... Gambar 8. Setelah Proses Filtering

d) Stemming merupakan tahap terakhir dari preprocessing. Tahap ini diperlukan selain untuk memperkecil jumlah indeks yang berbeda dari suatu dokumen, dapat pula melakukan penghapusan kata berimbuhan dan merubahnya menjadi kata dasar. Proses ini menggunakan Library Phyton Sastrawi yang merupakan library sederhana yang dapat mengolah kata berimbuhan bahasa Indonesia menjadi bentuk kata dasarnya.

[corona, adanya, china, bukan, sini, sini, cum... [menghilangkan, virus, mengkonsumsi, lebih, ba... [kunyah, daun, sirih, mengatasi, covid] [minum, kopi, x, sehari, menangkal, covid] [pelarangan, masker, politik, perusahaan]

[the, indonesia, big, stars, ajang, pencarian,... [bin, sumbang, alat, medis, obat, gugus, tugas... [pandemi, covid, perusahaan, negara, tetap, ra... [menjawab, pertanyaan, anak, kapan, pandemi, c... 「perawat, rsup, kariadi, positif, covid, menin... Gambar 9. Sebelum Proses Stemming

[corona, ada, china, bukan, sini, sini, cuma, .. [hilang, virus, konsumsi, lebih, banyak, makan... [kunyah, daun, sirih, atas, covid] [minum, kopi, x, hari, tangkal, covid] [larang, masker, politik, usaha]

7748 [the, indonesia, big, stars, ajang, cari, baka.. 7749 [bin, sumbang, alat, medis, obat, gugus, tugas... 7750 [pandemi, covid, usaha, negara, tetap, rampung... 7751 [jawab, tanya, anak, kapan, pandemi, covid, ak... 7752 [awat, rsup, kariadi, positif, covid, tinggal,... Gambar 10. Setelah Proses Stemming

3) Transformation: pada tahap ini dilakukan pembobotan kata dengan mencari nilai Tern Frequency (TF), namun sebelumnya dilakukan penghitungan jumlah kata pada judul berita seperti pada gambar di bawah ini: 


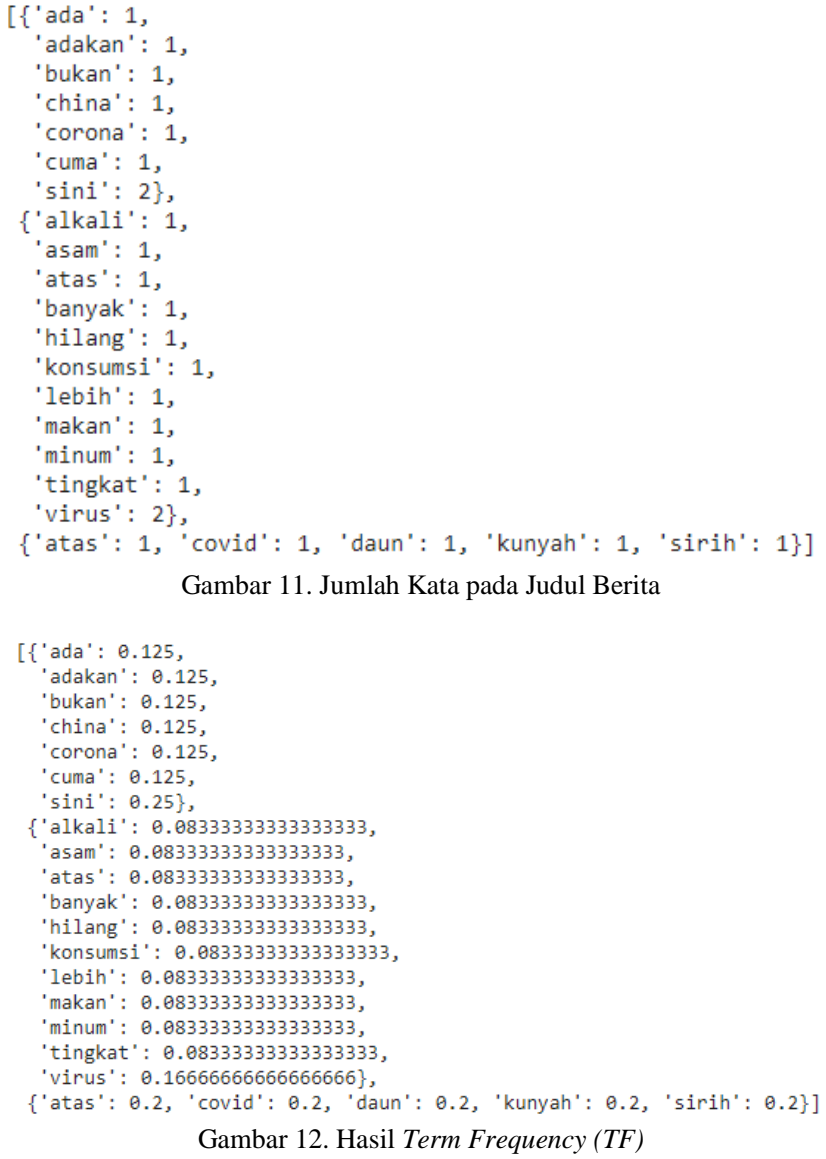

Kemudian setelah nilai TF dan IDF ditemukan dilakukan mencarian nilai TF-IDF dengan mengkalikan hasil keduanya.

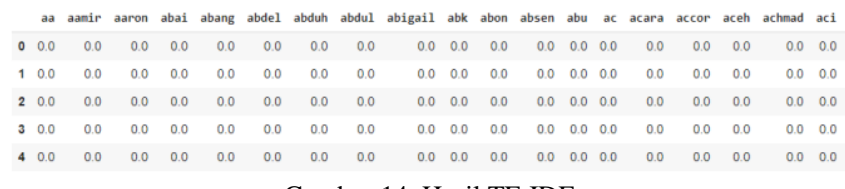

Gambar 14. Hasil TF-IDF

Perhitungan nilai TF secara manual dilakukan dengan persamaan (1).

$t f_{i}=\frac{\text { freq }_{i}(d j)}{\sum_{i=1}^{k} \text { freq }_{i}(d j)}$

Dilanjutkan dengan mencari nilai IDF dengan persamaan (2).

$i d f_{i}=\log \frac{|D|}{\left|\left\{d: t_{i} \in d\right\}\right|}$

Setelah kedua nilai didapatkan, dilakukan perhitungan manual nilai TF-IDF dengan persamaan (3).

$(t f-i d f)_{i j}=t f_{i} * i d f_{i}$

1) Data Mining: pada tahap ini dilakukan pemodelan menggunakan algoritma Support Vector Machine (SVM)
Setelah mendapatkan nilai TF selanjutnya dilakukan pencarian nilai IDF seperti pada gambar di bawah ini.

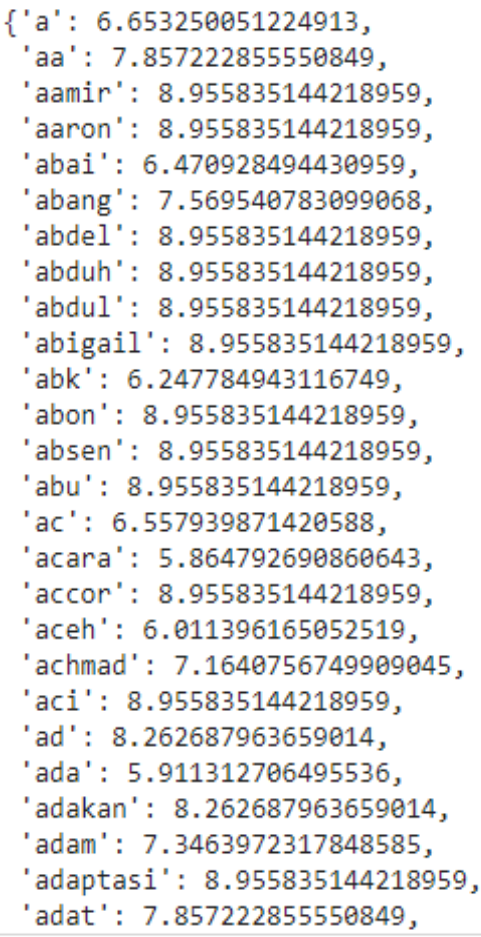

Gambar 13. Hasil Inverse Document Frequency (IDF)

dengan 2 fungsi kernel yaitu linear dan RBF. Pemodelan ini dilakukan pembagian data training dan data testing menjadi 4 skenario yaitu (60\%:40\%), (70\%:30\%), (80\%:20\%) dan (90\%:10\%). Pembagian ini dilakukan untuk mendapatkan nilai performa. Hasil pengolahan klasifikasi akan menghasilkan nilai tingkat akurasi, precision, recall, f-measure dan error rate. Pembagian data training dan data testing dapat dilihat pada tabel berikut.

TABEL III

Pembagian Data Training Dan Data Testing

\begin{tabular}{|l|l|l|}
\hline Skenario 1 & Data training (60\%) & Data testing (40\%) \\
\hline Skenario 2 & Data training (70\%) & Data testing (30\%) \\
\hline Skenario 3 & Data training (80\%) & Data testing (20\%) \\
\hline Skenario 4 & Data training (90\%) & Data testing (10\%) \\
\hline
\end{tabular}


Kemudian dilakukan pengujian terhadap tiap skenario dengan menggunakan 2 fungsi kernel yaitu kernel linear dan kernel RBF.

Skenario 1 (60:40): hasil dari pengujian SVM pada pemodelan klasifikasi berita hoax dan berita bukan hoax dengan skenario 1 adalah sebagai berikut.

- Pengujian dengan Kernel Linear

Kernel linear

$\begin{array}{crrrr} & & \text { predicted:hoax } & \text { predicted:bukan hoax } \\ \text { actual:hoax } & & 187 & & 156 \\ \text { actual:bukan hoax } & 93 & & 2833 \\ & & & & \\ & \text { precision } & \text { recall } & \text { f1-score } & \text { support } \\ 0 & 0.66786 & 0.54519 & 0.60032 & 343 \\ 1 & 0.94781 & 0.96822 & 0.95790 & 2926 \\ & & & & \\ \text { accuracy } & & & 0.92383 & 3269 \\ \text { Gambar 15. Hasil Pengujian SVM dengan } & \text { Kernel Linear Skenario 1 }\end{array}$

TABEL IV

Hasil Prediksi Svm Dengan Kernel Linear SKenario 1

\begin{tabular}{|c|c|}
\hline & Nilai \\
\hline True Positive & 187 \\
\hline True Negative & 2833 \\
\hline False Positif & 156 \\
\hline False Negative & 93 \\
\hline
\end{tabular}

- Pengujian dengan Kernel RBF

Kernel rbf

$$
\begin{aligned}
& \text { predicted:hoax predicted:bukan hoax } \\
& \begin{array}{lrr}
\text { actual: hoax } & 73 & 270 \\
\text { actual: bukan hoax } & 3 & 2923
\end{array} \\
& \text { precision recall f1-score support } \\
& \begin{array}{lllll}
0 & 0.96053 & 0.21283 & 0.34845 & 343
\end{array} \\
& \begin{array}{lllll}
1 & 0.91544 & 0.99897 & 0.95538 & 2926
\end{array} \\
& \begin{array}{lll}
\text { accuracy } & 0.91649 & 3269
\end{array}
\end{aligned}
$$

Gambar 16. Hasil Pengujian SVM dengan Kernel RBF Skenario 1

TABEL V

HASIl PREDIKSI SVM DENGAN KERNEL RbF SKENARIO 1

\begin{tabular}{|c|c|}
\hline & Nilai \\
\hline True Positive & 73 \\
\hline True Negative & 2923 \\
\hline False Positif & 270 \\
\hline False Negative & 3 \\
\hline
\end{tabular}

a) Skenario 2 (70:30): hasil dari pengujian SVM pada pemodelan klasifikasi berita hoax dan berita bukan hoax dengan skenario 2 adalah sebagai berikut:
- Pengujian dengan Kernel Linear Kernel linear

$$
\begin{aligned}
& \text { predicted:hoax predicted:bukan hoax } \\
& \begin{array}{lrr} 
& \text { predicted:hoax } & \text { predicted:bukan hoax } \\
\text { actual: hoax } & 149 & 107 \\
\text { actual:bukan hoax } & 77 & 2119
\end{array} \\
& \begin{array}{rrrr}
\text { precision } & \text { recall } & \text { f1-score } & \text { support } \\
& & & \\
0.65929 & 0.58203 & 0.61826 & 256 \\
0.95193 & 0.96494 & 0.95839 & 2196
\end{array} \\
& \begin{array}{lll}
\text { accuracy } & 0.92496 & 2452
\end{array}
\end{aligned}
$$

Gambar 17. Hasil Pengujian SVM dengan Kernel Linear Skenario 2

TABEL VI

Hasil PREDIKsi SvM DENGAN KERNEL LiNEAR SKENARIO 2

\begin{tabular}{|c|c|}
\hline & Nilai \\
\hline True Positive & 149 \\
\hline True Negative & 2119 \\
\hline False Positive & 107 \\
\hline False Negative & 77 \\
\hline
\end{tabular}

- Pengujian dengan Kernel RBF

Kernel rbf

$$
\begin{aligned}
& \text { predicted:hoax predicted:bukan hoax } \\
& \text { actual:hoax } 62 \quad 194 \\
& \text { actual:bukan hoax } \quad 3 \quad 2193 \\
& \text { precision recall f1-score support } \\
& \begin{array}{lllll}
0 & 0.95385 & 0.24219 & 0.38629 & 256
\end{array} \\
& \begin{array}{llll}
0.91873 & 0.99863 & 0.95702 & 2196
\end{array} \\
& \begin{array}{lll}
\text { accuracy } & 0.91966 & 2452
\end{array}
\end{aligned}
$$

Gambar 18. Hasil Pengujian SVM dengan Kernel RBF Skenario 2

TABEL VII

HASil PREDIKSI SvM DENGAN KERNEl RbF SKENARIO 2

\begin{tabular}{|c|c|}
\hline & Nilai \\
\hline True Positive & 62 \\
\hline True Negative & 2193 \\
\hline False Positive & 194 \\
\hline False Negative & 3 \\
\hline
\end{tabular}

b) Skenario 3 (80:20): hasil dari pengujian SVM pada pemodelan klasifikasi berita hoax dan berita bukan hoax dengan skenario 3 adalah sebagai berikut:

- Pengujian dengan Kernel Linear

Kernel linear

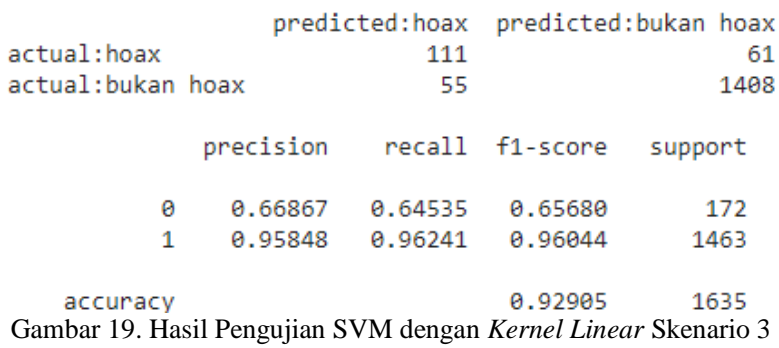


TABEL VIII

HASIL PREDIKSI SVM DENGAN KERNEL LINEAR SKENARIO 3

\begin{tabular}{|c|c|}
\hline & Nilai \\
\hline True Positive & 111 \\
\hline True Negative & 1408 \\
\hline False Positive & 61 \\
\hline False Negative & 55 \\
\hline
\end{tabular}

Kernel rbf

- Pengujian dengan Kernel RBF

\begin{tabular}{|c|c|c|c|c|}
\hline \multicolumn{3}{|r|}{ ted: hoax } & \multicolumn{2}{|c|}{ predicted:bukan hoax } \\
\hline actual: hoax & & 50 & & 122 \\
\hline actual: bukan & hoax & 3 & & 1460 \\
\hline & precision & recall & f1-score & support \\
\hline$\theta$ & 0.94340 & 0.29070 & 0.44444 & 172 \\
\hline 1 & 0.92288 & 0.99795 & 0.95895 & 1463 \\
\hline accuracy & & & 0.92355 & 1635 \\
\hline
\end{tabular}

TABEL IX

HASIL PREDIKSI SVM DENGAN KERNEL RbF SKENARIO 3

\begin{tabular}{|c|c|}
\hline & Nilai \\
\hline True Positive & 50 \\
\hline True Negative & 1460 \\
\hline False Positive & 122 \\
\hline False Negative & 3 \\
\hline
\end{tabular}

c) Skenario 4 (90:10): hasil dari pengujian SVM pada pemodelan klasifikasi berita hoax dan berita bukan hoax dengan skenario 1 adalah sebagai berikut:

- Pengujian dengan Kernel Linear Kernel linear

$$
\begin{array}{rrrrr} 
& & \text { predicted:hoax } & \text { predicted:bukan hoax } \\
\text { actual:hoax } & & 70 & & 33 \\
\text { actual:bukan hoax } & 29 & & 686 \\
& & & & \\
& \text { precision } & \text { recall } & \text { f1-score } & \text { support } \\
0 & 0.70707 & 0.67961 & 0.69307 & 103 \\
1 & 0.95410 & 0.95944 & 0.95676 & 715 \\
& & & & \\
\text { accuracy } & & & 0.92421 & 818
\end{array}
$$

Gambar 21. Hasil Pengujian SVM dengan Kernel Linear Skenario 4

TABEL X

\begin{tabular}{|c|c|c|c|c|c|c|c|c|}
\hline \multirow{3}{*}{\multicolumn{2}{|c|}{ Skenario }} & \multicolumn{3}{|c|}{ Akurasi (\%) } & \multicolumn{4}{|c|}{ Precision (\%) } \\
\hline & & \multirow{2}{*}{$\begin{array}{l}\text { Kernel } \\
\text { Linear }\end{array}$} & \multirow{2}{*}{\multicolumn{2}{|c|}{$\begin{array}{c}\text { Kernel } \\
\text { RBF }\end{array}$}} & \multicolumn{2}{|c|}{$\begin{array}{l}\text { Kernel } \\
\text { Linear }\end{array}$} & \multicolumn{2}{|c|}{$\begin{array}{c}\text { Kernel } \\
\text { RBF }\end{array}$} \\
\hline & & & & & 0 & 1 & 0 & 1 \\
\hline \multicolumn{2}{|c|}{$60: 40$} & 92.38 & \multicolumn{2}{|c|}{91.65} & 66.78 & $\begin{array}{l}94.7 \\
8\end{array}$ & $\begin{array}{l}96.0 \\
5\end{array}$ & $\begin{array}{l}91.5 \\
4\end{array}$ \\
\hline \multicolumn{2}{|c|}{$70: 30$} & 92.49 & \multicolumn{2}{|c|}{91.96} & 65.92 & $\begin{array}{l}95.1 \\
9\end{array}$ & $\begin{array}{l}95.3 \\
8\end{array}$ & $\begin{array}{l}91.8 \\
7\end{array}$ \\
\hline \multicolumn{2}{|c|}{$80: 20$} & 92.90 & \multicolumn{2}{|c|}{92.35} & 66.86 & $\begin{array}{l}95.8 \\
4\end{array}$ & $\begin{array}{l}94.3 \\
4\end{array}$ & $\begin{array}{l}92.2 \\
8\end{array}$ \\
\hline \multicolumn{2}{|c|}{$90: 10$} & 92.42 & \multicolumn{2}{|c|}{90.46} & 70.70 & $\begin{array}{l}95.4 \\
1\end{array}$ & $\begin{array}{l}90.3 \\
2\end{array}$ & $\begin{array}{l}90.4 \\
7\end{array}$ \\
\hline \multicolumn{4}{|c|}{ Recall (\%) } & \multicolumn{5}{|c|}{$F$-score (\%) } \\
\hline \multicolumn{2}{|c|}{$\begin{array}{l}\text { Kernel } \\
\text { Linear }\end{array}$} & \multicolumn{2}{|c|}{$\begin{array}{c}\text { Kernel } \\
\text { RBF }\end{array}$} & \multicolumn{2}{|c|}{$\begin{array}{l}\text { Kernel } \\
\text { Linear }\end{array}$} & \multicolumn{3}{|c|}{ Kernel RBF } \\
\hline 0 & 1 & 0 & 1 & 0 & 1 & 0 & & 1 \\
\hline $\begin{array}{c}54 . \\
51\end{array}$ & $\begin{array}{l}96 . \\
82\end{array}$ & $\begin{array}{c}21.2 \\
8\end{array}$ & $\begin{array}{l}99 . \\
89\end{array}$ & $\begin{array}{l}60 . \\
03\end{array}$ & 95.79 & 34.84 & & 53 \\
\hline $\begin{array}{l}58 . \\
20 \\
\end{array}$ & $\begin{array}{r}96 . \\
49 \\
\end{array}$ & $\begin{array}{c}24.2 \\
1 \\
\end{array}$ & $\begin{array}{l}99 . \\
86 \\
\end{array}$ & $\begin{array}{l}61 . \\
82 \\
\end{array}$ & 95.83 & 38.62 & & 70 \\
\hline $\begin{array}{l}64 . \\
53\end{array}$ & $\begin{array}{l}96 . \\
24\end{array}$ & $\begin{array}{c}29.0 \\
7\end{array}$ & $\begin{array}{l}99 . \\
79\end{array}$ & $\begin{array}{l}65 . \\
68\end{array}$ & 96.04 & 44.44 & & 89 \\
\hline $\begin{array}{l}67 . \\
96\end{array}$ & $\begin{array}{l}95 . \\
94\end{array}$ & $\begin{array}{c}27.1 \\
8\end{array}$ & $\begin{array}{r}99 . \\
58\end{array}$ & $\begin{array}{l}69 . \\
30\end{array}$ & 95.67 & 41.79 & & 48 \\
\hline
\end{tabular}

HASIL PREDIKSI SVM DENGAN KERNEL LINEAR SKENARIO 4

\begin{tabular}{|c|c|}
\hline & Nilai \\
\hline True Positive & 70 \\
\hline True Negative & 686 \\
\hline False Positive & 33 \\
\hline False Negative & 29 \\
\hline
\end{tabular}

- Pengujian dengan Kernel RBF

Kernel rbf

$$
\begin{aligned}
& \begin{array}{rrr} 
& \text { predicted:hoax } & \text { predicted:bukan hoax } \\
\text { actual:hoax } & 28 & 75
\end{array} \\
& \text { actual: bukan hoax } \\
& \text { precision recall f1-score support } \\
& \begin{array}{lllll}
0 & 0.90323 & 0.27184 & 0.41791 & 103
\end{array} \\
& \begin{array}{lllll}
1 & 0.90470 & 0.99580 & 0.94807 & 715
\end{array} \\
& \begin{array}{lll}
\text { accuracy } & 0.90465 & 818
\end{array}
\end{aligned}
$$

Gambar 22. Hasil Pengujian SVM dengan Kermel RBF skenario 4

TABEL XI

HASIL PREDIKSI SVM DENGAN KERNEL RBF SKENARIO 4

\begin{tabular}{|c|c|}
\hline & Nilai \\
\hline True Positive & 28 \\
\hline True Negative & 712 \\
\hline False Positive & 75 \\
\hline False Negative & 3 \\
\hline
\end{tabular}

5. Evaluation: Hasil yang diperoleh dari seluruh pengujian dengan model SVM akan dibandingkan untuk mengetahui model terbaik dalam proses klasifikasi. Hasil perbandingan evaluasi menggunakan 4 skenario dapat dilihat pada tabel berikut ini:

TABEL XII

PERBANDINGAN Evaluasi ModeI

Berdasarkan tabel di atas, dapat dilihat hasil akurasi menggunakan Support Vector Machine (SVM) dengan 2 fungsi kernel yaitu kernel linear mendapatkan nilai akurasi terbesar pada skenario 1 (60:40) sebesar 97,06\%. Sedangkan hasil akurasi terendah juga didapat kernel linear pada skenario 90:10 sebesar 95,87\%. Namun hasil dari nilai 
akurasi saja tidak cukup untuk menentukan model terbaik pada penelitian ini. Dapat dilihat juga hasil prediksi dari masing-masing kernel SVM dengan 4 skenario pada tabel 12.

Skenario 1 (60:40) dengan kernel linear mendapatkan hasil yang baik karena model dapat meng-klasifikasikan data berita hoax dan berita bukan hoax dengan baik, ditunjukan pada tabel di bawah.

TABEL XIII

HASIL PREDIKSI SVM DENGAN 2 FUNGSI KERNEL 4 SKENARIO

\begin{tabular}{|c|c|c|c|}
\hline Skenario & & Hasi & \\
\hline \multirow{8}{*}{ Skenario 60:40 } & \multicolumn{3}{|c|}{ Kernel Linear } \\
\hline & & $\begin{array}{l}\text { Prediksi } \\
\text { Hoax }\end{array}$ & $\begin{array}{c}\text { Prediksi Bukan } \\
\text { Hoax }\end{array}$ \\
\hline & Hoax & 187 & 156 \\
\hline & Bukan Hoax & 93 & 2833 \\
\hline & \multicolumn{3}{|c|}{ Kernel RBF } \\
\hline & & $\begin{array}{l}\text { Prediksi } \\
\text { Hoax }\end{array}$ & $\begin{array}{c}\text { Prediksi Bukan } \\
\text { Hoax }\end{array}$ \\
\hline & Hoax & 73 & 270 \\
\hline & Bukan Hoax & 3 & 2923 \\
\hline \multirow{8}{*}{ Skenario 70:30 } & \multicolumn{3}{|c|}{ Kernel Linear } \\
\hline & & $\begin{array}{l}\text { Prediksi } \\
\text { Hoax }\end{array}$ & $\begin{array}{c}\text { Prediksi Bukan } \\
\text { Hoax }\end{array}$ \\
\hline & Hoax & 149 & 107 \\
\hline & Bukan Hoax & 77 & 2119 \\
\hline & \multicolumn{3}{|c|}{ Kernel RBF } \\
\hline & & $\begin{array}{l}\text { Prediksi } \\
\text { Hoax }\end{array}$ & $\begin{array}{c}\text { Prediksi Bukan } \\
\text { Hoax }\end{array}$ \\
\hline & Hoax & 62 & 194 \\
\hline & Bukan Hoax & 3 & 2193 \\
\hline \multirow{8}{*}{ Skenario 80:20 } & \multicolumn{3}{|c|}{ Kernel Linear } \\
\hline & & $\begin{array}{l}\text { Prediksi } \\
\text { Hoax }\end{array}$ & $\begin{array}{c}\text { Prediksi Bukan } \\
\text { Hoax }\end{array}$ \\
\hline & Hoax & 111 & 61 \\
\hline & Bukan Hoax & 55 & 1408 \\
\hline & \multicolumn{3}{|c|}{ Kernel RBF } \\
\hline & & $\begin{array}{l}\text { Prediksi } \\
\text { Hoax }\end{array}$ & $\begin{array}{c}\text { Prediksi Bukan } \\
\text { Hoax }\end{array}$ \\
\hline & Hoax & 50 & 61 \\
\hline & Bukan Hoax & 3 & 1408 \\
\hline \multirow{8}{*}{ Skenario 90:10 } & \multicolumn{3}{|c|}{ Kernel Linear } \\
\hline & & $\begin{array}{l}\text { Prediksi } \\
\text { Hoax }\end{array}$ & $\begin{array}{c}\text { Prediksi Bukan } \\
\text { Hoax }\end{array}$ \\
\hline & Hoax & 70 & 33 \\
\hline & Bukan Hoax & 29 & 686 \\
\hline & \multicolumn{3}{|c|}{ Kernel RBF } \\
\hline & & $\begin{array}{l}\text { Prediksi } \\
\text { Hoax }\end{array}$ & $\begin{array}{c}\text { Prediksi Bukan } \\
\text { Hoax }\end{array}$ \\
\hline & Hoax & 28 & 75 \\
\hline & Bukan Hoax & 3 & 712 \\
\hline
\end{tabular}

\section{B. Pembahasan}

Penelitian ini mengimplementasikan algoritma Support Vector Machine (SVM) dalam mengklasifikasikan hoax dan bukan hoax berita Covid-19 yang diambil dari situs berita online. Metodelogi yang digunakan adalah proses text mining yang terdiri dari beberapa tahapan yaitu data selection, preprocessing, transformation, data mining dan evaluation.

Pada data selection dilakukan pengambilan data dengan proses web scrapping dan pemberian labeling, selanjutnya ke proses preprocessing dengan beberapa tahapan diantaranya case folding (mengubah keseluruhan kata dalam judul menjadi lowercase atau huruf kecil), tokenizing, filtering (penghapusan kata sambung) dan stemming (penghapusan kata imbuhan). Pada tahap transformation dilakukan pembobotan kata dengan menggunakan salah satu feature selection yaitu TF-IDF.

Pada pemodelan klasifikasi SVM dengan kernel linear dan RBF didapatkan hasil pengujian terbaik oleh kernel linear pada skenario 3 (80:20) karena model dapat mengklasifikasikan dengan baik data berita hoax dan berita bukan hoax Covid-19, yaitu dengan hasil data hoax yang diprediksi hoax ada 111, data hoax yang diprediksi bukan hoax ada 61. Data bukan hoax diprediksi hoax ada 55 dan data bukan hoax diprediksi bukan hoax ada 1408. Pada skenario (80:20) juga dapat dilihat bahwa kernel linear memiliki nilai akurasi tertinggi yaitu sebesar 92,90\%.

Sedangkan untuk nilai terendah didapat oleh kernel RBF pada skenario (90:10) yaitu 90,46\% dan model yang didapat juga kurang baik dalam mengklasifikasikan berita hoax maupun bukan hoax yaitu dengan hasil data hoax yang diprediksi sebagai hoax ada 28 dan data hoax yang diprediksi bukan hoax ada 75. Data bukan hoax yang diprediksi hoax ada 3 dan data bukan hoax yang diprediksi bukan hoax ada 712 .

\section{KESIMPULAN DAN SARAN}

\section{A. Kesimpulan}

Berdasarkan hasil penelitian yang telah dilakukan dapat disimpulkan beberapa hal, antara lain penerapan algoritma Support Vector Machine dengan kernel linear dan RBF untuk klasifikasi berita hoax Covid-19 dilakukan dengan menggunakan beberapa proses seperti case folding, tokenizing, filtering, stemming, pembobotan kata (TF-IDF) dan melakukan pemodelan dengan 4 skenario pengujian secara acak untuk mendapatkan model terbaik dari kedua kernel algoritma Support Vector Machine.

Algoritma Support Vector Machine (SVM) dengan kernel linear memiliki hasil prediksi yang bagus pada skenario 3 (80:20) karena model sanggup dalam mengklasifikasikan berita hoax dan bukan hoax covid-19. Hasil yang didapat yaitu ada 111 data hoax yang diprediksi hoax, ada 61 data hoax yang diprediksi bukan hoax. Sedangkan data bukan hoax yang diprediksi hoax ada 55 dan data bukan hoax diprediksi bukan hoax ada 1408. Selain itu akurasi yang didapat pada skenario 80:20 juga memiliki nilai akurasi tertinggi yaitu sebesar $92,90 \%$.

Sedangkan untuk nilai akurasi terendah didapat oleh kernel RBF pada skenario (90:10) yaitu 90,46\% dan model yang didapat juga kurang baik dalam mengklasifikasikan berita hoax maupun bukan hoax yaitu dengan hasil data hoax yang diprediksi hoax ada 28 \& data hoax yang diprediksi bukan hoax ada 75. Data bukan hoax yang diprediksi hoax ada 3 \& data bukan hoax yang diprediksi bukan hoax ada 712 . 


\section{B. Saran}

Penelitian ini masih belum sempurna dan membutuhkan pengembangan lebih lanjut. Oleh karena itu, peneliti menyarankan hal yang dapat menjadi saran untuk mengembangkan penelitian selanjutnya yaitu diharapkan dapat menangani imbalance data untuk proses klasifikasi berita hoax dan bukan hoax covid-19 serta mampu menerapkan hasil pemodelan klasifikasi pada sistem

\section{DAFTAR PUSTAKA}

[1] Kementerian Pendidikan dan Kebudayaan Republik Indonesia, "Arti Kata Hoax," Kamus Besar Bahasa Indonesia, 2021 https://kbbi.kemdikbud.go.id/entri/hoaks.

[2] Oxford University, "Oxford Learners Dictionaries," Oxford University Press, 2021. https://www.oxfordlearnersdictionaries.com/definition/english/hoax 1 ? $\mathrm{q}=$ hoax.

[3] MASTEL, "Hasil Survey Wabah Hoax Nasional 2019," MASTEL, 2019. https://mastel.id/hasil-survey-wabah-hoax-nasional-2019/ (accessed Jan. 24, 2021).

[4] Simon Kemp, "DIGITAL 2019: INDONESIA," Data Reportal, 2019. https://datareportal.com/reports/digital-2019-indonesia

[5] Simon Kemp, "Digital 2020: Indonesia," Data Reportal, 2020. https://datareportal.com/reports/digital-2019-indonesia

[6] A. F. I. Tachta Citra Elfira, "APJII: Pandemi COVID-19 Buat Pengguna Internet di Indonesia Meningkat Hampir 200 Juta," voi.id, 2020. https://voi.id/teknologi/19331/apjii-pandemi-covid-19-buatpengguna-internet-di-indonesia-meningkat-hampir-200-juta.

[7] Kementerian Pendidikan dan Kebudayaan Republik Indonesia, "Arti kata Berita," Kamus Besar Bahasa Indonesia, 2021 https://kbbi.kemdikbud.go.id/entri/berita.

[8] A. M. Hasan, "Info Hoax Soal Kesehatan Paling Banyak Beredar di Masyarakat," tirto.id, 2017. https://tirto.id/info-hoax-soal-kesehatanpaling-banyak-beredar-di-masyarakat-cnQZ.

[9] Tim Detikcom, "Kapan Sebenarnya Corona Pertama Kali Masuk RI?," Detikcom, 2020. https://news.detik.com/berita/d-4991485/kapansebenarnya-corona-pertama-kali-masuk-ri?single $=1$.

[10] C. Juditha, "People Behavior Related To The Spread Of Covid-19's Hoax," J. Pekommas, vol. 5, no. 2, p. 105, 2020, doi: 10.30818/jpkm.2020.2050201.
[11] F. N. Ulya and B. P. Jatmiko, "Kompas.com Kembali Jadi Pemenang Kategori Media Online Tepercaya," Kompas.com, 2019. https://money.kompas.com/read/2019/08/01/124215826/kompascomkembali-jadi-pemenang-kategori-media-online-tepercaya?page=all .

[12] H. Margianto, "Kompas.com Tersertifikasi dalam Jaringan Internasional Penguji Informasi," Kompas.com, 2018 https://nasional.kompas.com/read/2018/10/17/08133311/kompascom -tersertifikasi-dalam-jaringan-internasional-penguji-informasi .

[13] R. P. Aji, "Pelatihan Identifikasi dan Pelaporan Berita Hoax melalui portal 'turnbackhoax.id ' kepada Masyarakat Desa Kedungwringin," vol. 1 , no. 2 , pp. 120-127.

[14] F. Prayoga, "Gugus Tugas Covid-19 Luncurkan Situs Resmi, Berisi Edukasi hingga Hoax Buster," Okezone, 2020 https://nasional.okezone.com/read/2020/03/19/337/2186044/gugustugas-covid-19-luncurkan-situs-resmi-berisi-edukasi-hingga-hoaxbuster.

[15] H. Hermanto, A. Mustopa, and A. Y. Kuntoro, "Algoritma Klasifikasi Naive Bayes Dan Support Vector Machine Dalam Layanan Komplain Mahasiswa," JITK (Jurnal Ilmu Pengetah. dan Teknol. Komputer), vol. 5, no. 2, pp. 211-220, 2020, doi: 10.33480/jitk.v5i2.1181.

[16] P. Assiroj, Meyliana, A. N. Hidayanto, H. Prabowo, and H. L. H. S. Warnars, "Hoax News Detection on Social Media: A Survey," 1st 2018 Indones. Assoc. Pattern Recognit. Int. Conf. Ina. 2018 - Proc., pp. 186-191, 2019, doi: 10.1109/INAPR.2018.8627053.

[17] H. Mustofa and A. A. Mahfudh, "Klasifikasi Berita Hoax Dengan Menggunakan Metode Naive Bayes," Walisongo J. Inf. Technol., vol. 1, no. 1, p. 1, 2019, doi: 10.21580/wjit.2019.1.1.3915.

[18] D. Maulina and R. Sagara, "Klasifikasi Artikel Hoax Menggunakan Support Vector Machine Linear Dengan Pembobotan Term Frequency-Inverse Document Frequency,” J. Mantik Penusa, vol. 2, no. 1, pp. 35-40, 2018.

[19] M. R. A. Nasution and M. Hayaty "Perbandingan Akurasi dan Waktu Proses Algoritma K-NN dan SVM dalam Analisis Sentimen Twitter," J. Inform., vol. 6, no. 2, pp. 226-235, 2019, doi: 10.31311/ji.v6i2.5129.

[20] A. T. Akhir, "1 , 2, 3."

[21] Y. Wulandari, Wiranto, and Wiharto, "Klasifikasi Keluhan Pelanggan Berbasis Twitter Menggunakan Metode Support Vector Machine (Svm) (Studi Kasus Pos Indonesia), Pus. Dokumentasi dan Inf. Ilm. UNS, p. 1, 2017, [Online]. Available: https://eprints.uns.ac.id/43593/. 